\title{
ON CONDENSED MILK.
}

By Oтto Hehner, F.C.S.

Read before the Society of Public Analysts, on 19th February, 1879.

OUR information as to the composition of the article known as condensed milk is somewhat contradictory. Thus Hassall gives four closely agreeing analyses, of which the following is the average :-

$\begin{array}{lcccccccr}\text { Water... } & \ldots & \ldots & \ldots & \ldots & \ldots & \ldots & \ldots & 25 \cdot 68 \\ \text { Casein } & \ldots & \ldots & \ldots & \ldots & \ldots & \ldots & \ldots & 16 \cdot 85 \\ \text { Milk sugar } & \ldots & \ldots & \ldots & \ldots & \ldots & \ldots & \ldots & 15 \cdot 35 \\ \text { Cane sugar } & \ldots & \ldots & \ldots & \ldots & \ldots & \ldots & \ldots & 28.98 \\ \text { Fat ... } & \ldots & \ldots & \ldots & \ldots & \ldots & \ldots & \ldots & 10.27 \\ \text { Mineral matter } & \ldots & \ldots & \ldots & \ldots & \ldots & \ldots & 280 \\ \end{array}$

In consonance with these figures are those of Church. Wanklyn, on the contrary, states the contents as under:-

\begin{tabular}{lcccccccr} 
Water... &. & $\ldots$ & $\ldots$ & $\ldots$ & $\ldots$ & $\ldots$ & $\ldots$ & $20 \cdot 5$ \\
Fat $\ldots$ & $\ldots$ & $\ldots$ & $\ldots$ & $\ldots$ & $\ldots$ & $\ldots$ & $\ldots$ & $10 \cdot 4$ \\
Casein &.. & $\ldots$ & $\ldots$ & $\ldots$ & $\ldots$ & $\ldots$ & $\ldots$ & $11 \cdot 0$ \\
Ash $\ldots$ & $\ldots$ & $\ldots$ & $\ldots$ & $\ldots$ & $\ldots$ & $\ldots$ & $\ldots$ & $2 \cdot 0$ \\
Cane and milk sugar... & $\ldots$ & $\ldots$ & $\ldots$ & $\ldots$ & $\ldots$ & $56 \cdot 1$ \\
\hline
\end{tabular}

From the former of these analyses, assuming that the original milk contained $9 \cdot 3$ per cent. of solids not fat, I calculate that 3.76 parts of milk have been condensed into one part, and that the original milk contained $2 \cdot 7$ per cent of fat, and 0.74 of ash.

Wanklyn does not give the millk sugar separately, but calculating this, from the average composition of milk, to be $12 \cdot 6$, a figure which certainly cannot be far wrong, we obtain as milk solids not fat, $25 \cdot 6$ per cent, or a condensation of $2 \cdot 75: 1$, the original milk containing 3.8 per cent. of fat, and 0.72 per cent. of ash.

Condensed milk being now very largely consumed, not only as an addition to coffee, tea, etc., but principally as exclusive food for infants, it seemed to me a matter of somc importance to ascertain which of these conflicting analyses was correct, and the exact proportion of condensation of the various brands of condensed milk now in the market.

I purchased at different shops what I suppose are average samples of condensed milk. The prices paid varied from 5d. to $7 \mathrm{~d}$. per one pound tin.

The analysis was conducted somewhat differently from the method usually employed, because it was found to be quite impossible to completely extract the fat from 
the total solids by means of ether or benzoline, the large amount of cane sugar effectually protecting the fat. About 20 grms. were diluted with water so as to make 250 c.c., in 10 c.c. of this milk the total solids and the mineral matter were determined as customary; for casein and fat twice 25 c.c. were precipitated with a drop or two of acetic acid, and the coagulated casein, containing all the fat, collected on a weighed filter. In the one portion the casein and fat were weighed, from the other the fat was extracted by means of alcohol and ether, and the casein thus obtained. The milk sugar was determined gravimetrically by means of copper solution, and I adopted as basis of calculation the figures quite recently worked out by Rodewald and Tollens (Berl. Ber. XI., p. 2076), who, as the result of a most careful investigation, came to the conclusion that aithough the time of heating, the dilution of the solutions, and the proportion of excess of Fehling's solution employed, are all of some influence upon the proportion of cupric oxyde reduced, yet in any case but a small error could be committed by fixing the reducing power of one molecule of milk sugar at $7 \cdot 47$ eq. of copper.

The cane sugar was generally deduced by difference, but in a few cases I determined it directly, and obtained as concordant results as could well be expected.

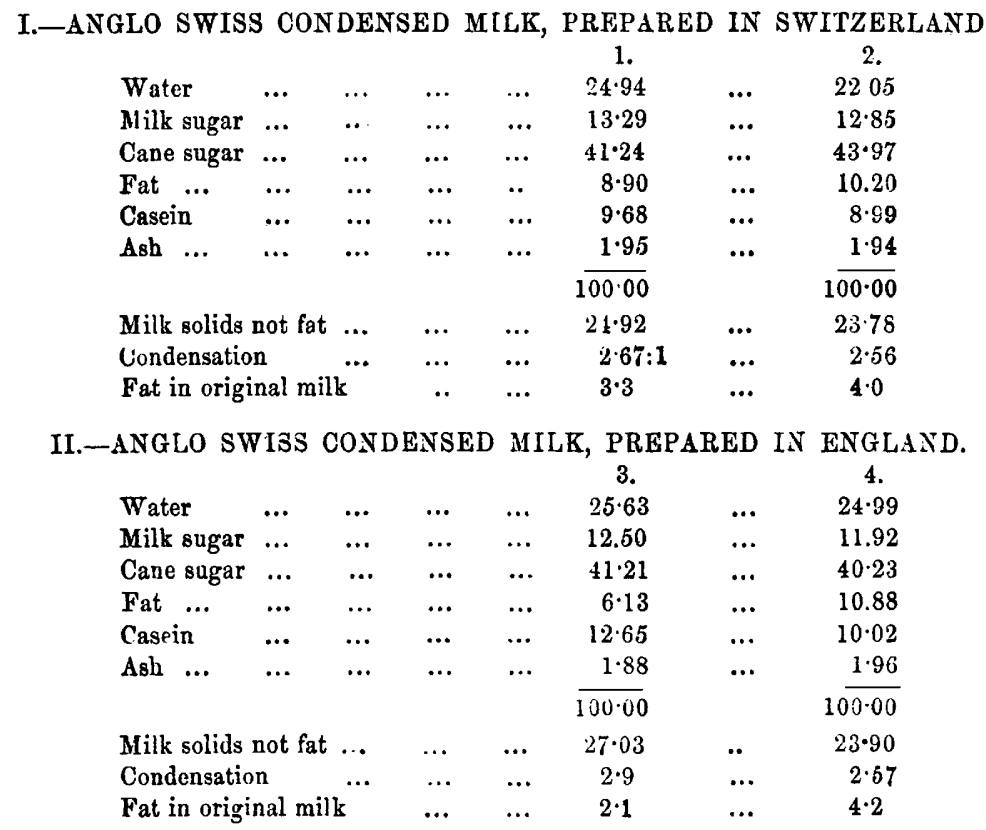

III.-NORWEGIAN CONDENSED MILK.

$\begin{array}{lccccccr} & & & & & 5 . & & 6 . \\ \text { Water } & \ldots & \ldots & \ldots & \ldots & 28 \cdot 85 & \ldots & 29 \cdot 05 \\ \text { Milk sugar } & \ldots & \ldots & \ldots & \ldots & 14 \cdot 14 & \ldots & 12 \cdot 70 \\ \text { Cane sugar } & \ldots & \ldots & \ldots & \ldots & 36 \cdot 74 & \ldots & 38.14 \\ \text { Fat .. } & \ldots & \ldots & \ldots & \ldots & 9 \cdot 21 & \ldots & 9 \cdot 66 \\ \text { Casein } & \ldots & \ldots & \ldots & \ldots & 8 \cdot 98 & \ldots & 8 \cdot 58 \\ \text { Ash } \ldots & \ldots & \ldots & \ldots & \ldots & 2 \cdot 08 & \ldots & 1 \cdot 87 \\ & & & & & 100 \cdot 00 & & 100 \cdot 00 \\ \text { Milk solids not fat } & \ldots & \ldots & \ldots & 25 \cdot 20 & \ldots & 22 \cdot 52 \\ \text { Condensation } & \ldots & \ldots & \ldots & 2 \cdot 71 & \ldots & 2.49 \\ \text { Fat in original milk... } & \ldots & \ldots & 3 \cdot 4 & \ldots & 3 \cdot 9\end{array}$


From the tin containing sample 6 a quantity of gas escaped on opening, and soon a large proportion of the contents of the tin ran over in active fermentation.

\section{HELVETIA.}

\begin{tabular}{|c|c|c|c|c|c|c|c|}
\hline & \multirow[b]{2}{*}{$\ldots$} & \multirow[b]{2}{*}{$\ldots$} & & \multirow[b]{2}{*}{$\begin{array}{c}8 . \\
26 \cdot 37\end{array}$} \\
\hline & & & & $\ldots$ & $\begin{array}{c}7 . \\
25 \cdot 29\end{array}$ & $\ldots$ & \\
\hline Milk sugar & $\ldots$ & $\ldots$ & $\ldots$ & $\ldots$ & $13 \cdot 01$ & $\ldots$ & $13 \cdot 21$ \\
\hline Cane sugar & $\ldots$ & $\ldots$ & $\ldots$ & $\ldots$ & 41.04 & $\ldots$ & $40 \cdot 27$ \\
\hline Fat ... & $\ldots$ & $\ldots$ & $\ldots$ & $\ldots$ & $7 \cdot 19$ & $\ldots$ & 6.98 \\
\hline Casein & $\ldots$ & $\ldots$ & $\ldots$ & $\ldots$ & $11 \cdot 73$ & $\ldots$ & $11 \cdot 34$ \\
\hline \multirow[t]{2}{*}{ Ash ... } & \multirow[t]{2}{*}{$\ldots$} & \multirow[t]{2}{*}{$\ldots$} & \multirow[t]{2}{*}{$\ldots$} & \multirow[t]{2}{*}{$\ldots$} & $1 \cdot 74$ & $\ldots$ & 1.83 \\
\hline & & & & & $100 \cdot 00$ & & $\overline{100.00}$ \\
\hline \multirow{3}{*}{\multicolumn{3}{|c|}{$\begin{array}{l}\text { Milk solids not fat ... } \\
\text { Condensation } \quad \ldots\end{array}$}} & $\ldots$ & $\ldots$ & $26 \cdot 48$ & $\ldots$ & $26 \cdot 3$ \\
\hline & & & $\ldots$ & $\ldots$ & $2 \cdot 85$ & $\ldots$ & $2 \cdot 8$ \\
\hline & & & $\ldots$ &.. & $2 \cdot 5$ & $\ldots$ & $2 \cdot 5$ \\
\hline
\end{tabular}

GERBER \& CO.'S CONDEATSED MILK.

$\begin{array}{llrrrrrr} & & & & & 9 . & & 10 . \\ \text { Water } & \ldots & \ldots & \ldots & \ldots & 23.68 & \ldots & 24 \cdot 47 \\ \text { Milk sugar } & \ldots & \ldots & \ldots & \ldots & 12.93 & \ldots & 12.23 \\ \text { Cane sugar } & \ldots & \ldots & \ldots & \ldots & 41.80 & \ldots & 40.31 \\ \text { Fat } \ldots & \ldots & \ldots & \ldots & \ldots & 9 \cdot 74 & \ldots & 12 \cdot 76 \\ \text { Casein } & \ldots & \ldots & \ldots & \ldots & 9 \cdot 80 & \ldots & 8.22 \\ \text { Ash } \ldots & \ldots & \ldots & \ldots & \ldots & 2 \cdot 05 & \ldots & 2.01 \\ & & & & & 100.00 & & 100.00 \\ \text { Milk solids not fat } & \ldots & \ldots & \ldots & 24.81 & \ldots & 22 \cdot 46 \\ \text { Condensation } & \ldots & \ldots & \ldots & 2 \cdot 6 & \ldots & 2 \cdot 41 \\ \text { Fat in original milk... } & \ldots & \ldots & 3.7 & \ldots & 5.3\end{array}$

"OREAM MILK," HOOKER'S PROCESS.

\begin{tabular}{|c|c|c|c|c|c|c|c|}
\hline Water & $\ldots$ & ... & ... & $\ldots$ & $\begin{array}{c}11 . \\
19 \cdot 11\end{array}$ & $\ldots$ & $\begin{array}{c}12 . \\
18 \cdot 94\end{array}$ \\
\hline Milk Sugar & $\ldots$ & $\ldots$ & $\ldots$ & $\ldots$ & 13.75 & $\ldots$ & $13 \cdot 68$ \\
\hline Cane Sugar & $\ldots$ & $\ldots$ & $\ldots$ & $\ldots$ & $44 \cdot 11$ & $\ldots$ & 42.92 \\
\hline Fat $\ldots$ & $\ldots$ & $\ldots$ & $\ldots$ & $\ldots$ & $10 \cdot 27$ & $\ldots$ & $11 \cdot 77$ \\
\hline Casein & $\ldots$ & $\ldots$ & $\ldots$ & $\ldots$ & $10 \cdot 66$ & $\ldots$ & $10 \cdot 47$ \\
\hline Ash $\ldots$ & $\ldots$ & $\ldots$ & $\ldots$ & $\ldots$ & $2 \cdot 10$ & $\ldots$ & $2 \cdot 2$ \\
\hline & & & & & $\overline{100 \cdot 00}$ & & $\overline{100 \cdot 00}$ \\
\hline \multirow{2}{*}{\multicolumn{3}{|c|}{$\begin{array}{l}\text { Milk solids not fat ... } \\
\text { Condensation }\end{array}$}} & $\ldots$ & $\cdots$ & 26.51 & & $26 \cdot 3$ \\
\hline & & & $\ldots$ & $\ldots$ & $2 \cdot 85$ & & $2 \cdot 8$ \\
\hline \multicolumn{3}{|c|}{ Fat, in original milk } & $\ldots$ & $\ldots$ & $3 \cdot 6$ & & 4 \\
\hline
\end{tabular}

Both these samples were very lumpy, and contained large crystals of sugar.

\section{NESTLE'S SWISS MILK.}

$\begin{array}{llllllllr}\text { Water... } & \ldots & \ldots & \ldots & \ldots & \ldots & \ldots & \ldots & 16.30 \\ \text { Milk Sugar } & \ldots & \ldots & \ldots & \ldots & \ldots & \ldots & \ldots & 13.62 \\ \text { Cane Sugar } & \ldots & \ldots & \ldots & \ldots & \ldots & \ldots & \ldots & 50.08 \\ \text { Fat } \ldots & \ldots & \ldots & \ldots & \ldots & \ldots & \ldots & \ldots & 8.85 \\ \text { Casein... } & \ldots & \ldots & \ldots & \ldots & \ldots & \ldots & \ldots & 8 \cdot 98 \\ \text { Ash } \ldots & \ldots & \ldots & \ldots & \ldots & \ldots & \ldots & \ldots & 2 \cdot 17 \\ & & & & & & & & 100 \cdot 00 \\ \text { Milk Solids not fat } & \ldots & \ldots & \ldots & \ldots & \ldots & \ldots & 25.77 \\ \text { Condensation } \ldots & \ldots & \ldots & \ldots & \ldots & \ldots & \ldots & 2.76 \\ \text { Fat in Original } & \text { Milk } \ldots & \ldots & \ldots & \ldots & \ldots & \ldots & 3.2\end{array}$


The amount of milk solids not fat varied, therefore, from 22.46 to 27.03 per cent., corresponding to a condensation of from 2.41 to 2.9 into one part; the fat fluctuated between 6.13 and 12.76 per cent., or in the original milk from $2 \cdot 1$ to 5.3 per cent., the cane sugar from 36.74 to 50.08 per cent., and the mineral matter from 1.74 to 2.20 , average 1.98 per cent.

Only in one case was there a deficiency of fat, that is to say the original milk must have been skimmed; in two others it came just to the lowest limit of genuine milk, namely $2 \cdot 5$ per cent.

The average amount of condensation was $2 \cdot 69: 1$, or, in order to get a milk containing the same amount of milk solids not fat as did the original milk, to one part $b y$ weight of the condensed milk, 1.69 parts by weight of water must be added.

I found the specific gravity of three of the above milks to be $1.2 \varepsilon 3,1.272$ and $1 \cdot 287$, average $1 \cdot 281$.

Hence, as the average amount of milk solids not fat was 25.09 per cent., to one part by volume of condensed milk $2 \cdot 45$ parts by volume of water must be added to obtain $a$ liquid with 9.3 per cent. of milk solids not fat. The amount of total solids (average on the manufactured article 76.26 per cent.) contained in the milk would then, on account of the very large amount of cane sugar, be 28.3 per cent.

If, however, we dilute the milk to 12 per cent. of total solids, then the casein, its most important constituent, is reduced to less than one half the proper quantity.

Now contrast with this calculation the directions given by the manufacturers. I lay no stress upon the proportions of water recommended to be added to make a milk suitable for culinary purposes, but take the directions laid down for the preparation of milk intended for infant's food, because we have a good standard, namely the composition of human milk, whereby to measure these artificial liquids, "For infants add 7 to 10 parts of water" (Anglo-Swiss made abroad), "add 7 to 14 parts of water" (AngloSwiss made in England), " 7 to 10 parts of water" (Helvetia), "from 15 to 18 parts of water" (Norwegian).

Assuming that human milk contains one third less casein than cow's milk does, we ought to add, instead of the 2.45 volumes as given above, to one spoonful of condensed milk 3.6 of water, instead of from 7 to 18 ! If the dilution is actually made in the proportion of 1 to 18 , then the liquid is hardly better than a very dilute solution of cane sugar, containing no more than 0.68 per cent. of casein, instead of upwards of 3 per cent. as contained in human milk. This wash would be a starving diet indeed.

In human milk the proportion of nitrogenous matter to saccharine matter ( 1 fat $=2 \cdot 4$ sugar in effect) is as $1: 4 \cdot 3$, in condensed milk as $1: 7 \cdot 7$

Condensed milk, howerer excellent and valuable it may be in many cases as a substitute for fresh milk when the latter cannot be had, appears hence to be totally and absolutely unfit to be used as a substitute for mother's milk.

I have no doubt that both Hassall's and Church's analyses are correct. If so, condensed milk must of late years have materially deteriorated and become much thinner than it was when those gentlemen made their analyses. $3 \frac{3}{4}$ parts of milk were then condensed to one part; now only $2 \frac{2}{3}$ are evaporated to one, whilst the price has not, as far as I am aware, correspondingly decreased.

One tin of condensed milk, when properly diluted with water makes $2 \frac{3}{4}$ pints of fluid milk. Reckoning the price of one pint of fresh milk at twopence halfpenny, $2 s$ pints 
would cost less than sevenpence, the price often charged for the condensed milk. Hence there is no advantage, on the score of economy, on the side of condensed milk.

There is another most objectionable statement made in connection with some of these milks. Both on the Anglo-Swiss and on the brand bearing the name 'Nestle' it is directed "add less water (than 1:5) and it is equivalent to cream." $\Delta$ s cream itself ought to contain no less than from 25 to 30 per cent. of fat, it is evident that no amount of dilution could make condensed milk, with its 6 to 12 per cent. of fat, "equivalent to cream." I am not sure whether this declaration, from the side of the manufacturers, does not bring the brands in question under the scope of the Sale of Food and Drugs Act.

Through the kindness of Dr. Sterenson, of Guy's Hospital, I was enabled to examine a sample of Italian condensed milk. This article formed a pasty mass of the consistency of butter. It contained water $37 \cdot 1$ per cent., milk sugar 18.89 per cent., and mineral salts 3.07 per cent., from which incomplete data the condensation may be approximately calculated as $4 \cdot 6: 1$. It does not appear to contain any cane sugar, or, if any, but a very small quantity.

From one of the samples of which I have detailed the analysis, I isolated the fat. This furnished 88.1 per cent. of insoluble fatty acids, and hence was genuine butter-fat.

Mr. Wigner said that in determining the milk-sugar by copper solution after coagulating with acetic acid and inverting, it was quite improbable that the results would have been within 5 per cent. of the truth. The difficulties of this determination were so great that it was rather by fortunate work than by the accuracy of the processes available and used that the totals cast up as these did. As to the sample of Italian milk, he might say that condensed milk made without sugar, could be obtained in London in almost any quantity. With regard to the ash being the most correct estimation in the whole analysis, and therefore the one from which the proportion of concentration could bo most fairly checked, he thought that in doing that Mr. Hehner must have omitted to notice the fact that the class of sugar used for the purpose always contained a large amount of ash itself, often considerably in excess of that found in the milk, so that it would be impossible to take the ash as a reliable basis, unless an allowance were made for the salts present in the sugar. Again, if he took it correctly, the figures $2 \cdot 76$ of concentration were drawn from the solids not fat. During the concentration of milk with sugar, even in a vacuum pan, the casein underwent very rapid decomposition, and the consequence was that the nitro genous matters in milk were very considerably altered during concentration. If a milk containing 3.5 casein were taken, and 40 parts were concentrated into 10 parts, instead of finding 14 parts casein, less than 10 would be found, as calculated from the ordinary nitrogen combustion. Mr. Wigner thought that whereas by Mr. Hehner's tables, 2.76 gallons, were being concentrated into one, the probability was that that 3.76 gallons were being concentrated into one. He would have much liked to have seen the analysis of the ash. The ash of sugar was largely alkaline carbonates. $\mathrm{He}$ did not know whether it had been mentioned, but the ash of milk contained almost 10 per cent. of its weight of chlorine.

After some renarks from Dr. Dupré and Mr. Hehner,

Dr. Muter said he agreed in condemning condensed milk as food, as he looked upon it as a most abominable thing for diet. If it were diluted sufficiently for an infant to digest it it was of no value as a food, and, if on the other hand, it were only diluted so that the casein should be as nutritive as in woman's milk, then an infant could not digest it. It was the cause of the death of many infants. 